\title{
A Stimulating Recollection of Low-Frequency Internal Motions (Phonons) in Biomacromolecules
}

\author{
Kuo-Chen Chou \\ Gordon Life Science Institute, Boston, MA, USA \\ Email: kcchou@gordonlifescience.org,kcchou38@gmail.com
}

How to cite this paper: Chou, K.-C. (2020). A Stimulating Recollection of Low-Frequency Internal Motions (Phonons) in Biomacromolecules. Voice of the Publisher, 6, 164 166. https://doi.org/10.4236/vp.2020.64019

Received: September 15, 2020

Accepted: November 14, 2020

Published: November 17, 2020

Copyright $\odot 2020$ by author(s) and Scientific Research Publishing Inc. This work is licensed under the Creative Commons Attribution International License (CC BY 4.0).

http://creativecommons.org/licenses/by/4.0/

\begin{abstract}
In this short review paper, the significant and profound impacts of the Chou's low-frequency internal motions in protein and DNA molecules have been briefly presented with crystal clear convincingness.
\end{abstract}

\section{Keywords}

Low-Frequency Phonons, Internal Motions, Biomacromolecules, Significant Impacts, Profound Impacts

The first paper introducing the low-frequency internal motions or phonons was proposed in 1977 [1]. It has stimulated a series of follow-up papers in this very interesting field (see, e.g., [2]-[16], as well as the eight master pieces of papers from the then Chairman of Nobel Prize Committee Sture Forsen [2] [17]-[23].

It is indeed very significant by introducing the concept of low-frequency internal motions (phonons) for studying biomacromolecules and it is indeed very profound by doing the same.

\section{Conflicts of Interest}

The author declares no conflicts of interest regarding the publication of this paper.

\section{References}

[1] Chou, K.C. and Chen, N.Y. (1977) The Biological Functions of Low-Frequency Phonons. Scientia Sinica, 20, 447-457.

[2] Chou, K.C., Chen, N.Y. and Forsen, S. (1981) The Biological Functions of LowFrequency Phonons: 2. Cooperative Effects. Chemica Scripta, 18, 126-132. 
[3] Chou, K.C. and Kiang, Y.S. (1985) The Biological Functions of Low-Frequency Phonons: 5. A Phenomenological Theory. Biophysical Chemistry, 22, 219-235. https://doi.org/10.1016/0301-4622(85)80045-4

[4] Chou, K.C. (1987) The Biological Functions of Low-Frequency Phonons: 6. A Possible Dynamic Mechanism of Allosteric Transition in Antibody Molecules. Biopolymers, 26, 285-295. https://doi.org/10.1002/bip.360260209

[5] Chou, K.C. and Maggiora, G.M. (1988) The Biological Functions of Low-Frequency Phonons: 7. The Impetus for DNA to Accommodate Intercalators. British Polymer Journal, 20, 143-148. https://doi.org/10.1002/pi.4980200209

[6] Chou, K.C. (1984) The Biological Functions of Low-Frequency Phonons. 4. Resonance Effects and Allosteric Transition. Biophysical Chemistry, 20, 61-71. https://doi.org/10.1016/0301-4622(84)80005-8

[7] Chou, K.C. (1984) Biological Functions of Low-Frequency Vibrations (Phonons). 3. Helical Structures and Microenvironment. Biophysical Journal, 45, 881-889. https://doi.org/10.1016/S0006-3495(84)84234-4

[8] Chou, K.C. (1983) Identification of Low-Frequency Modes in Protein Molecules. Biochemical Journal, 215, 465-469. https://doi.org/10.1042/bj2150465

[9] Chou, K.C. (1985) Low-Frequency Motions in Protein Molecules: Beta-Sheet and Beta-Barrel. Biophysical Journal, 48, 289-297. https://doi.org/10.1016/S0006-3495(85)83782-6

[10] Chou, K.C. (1989) Low-Frequency Resonance and Cooperativity of Hemoglobin. Trends in Biochemical Sciences, 14, 212-213. https://doi.org/10.1016/0968-0004(89)90026-1

[11] Chou, K.C. (1984) Low-Frequency Vibrations of DNA Molecules. Biochemical Journal, 221, 27-31. https://doi.org/10.1042/bj2210027

[12] Chou, K.C. (1983) Low-Frequency Vibrations of Helical Structures in Protein Molecules. Biochemical Journal, 209, 573-580. https://doi.org/10.1042/bj2090573

[13] Chou, K.C. (1986) Origin of Low-Frequency Motion in Biological Macromolecules: A View of Recent Progress of Quasi-Continuity Model. Biophysical Chemistry, 25, 105-116. https://doi.org/10.1016/0301-4622(86)87001-6

[14] Chou, K.C. (1985) Prediction of a Low-Frequency Mode in Bovine Pancreatic Trypsin Inhibitor Molecule. International Journal of Biological Macromolecules, 7, 77-80. https://doi.org/10.1016/0141-8130(85)90035-2

[15] Chou, K.C., Maggiora, G.M. and Mao, B. (1989) Quasi-Continuum Models of TwistLike and Accordion-Like Low-Frequency Motions in DNA. Biophysical Journal, 56, 295-305. https://doi.org/10.1016/S0006-3495(89)82676-1

[16] Chou, K.C. (1988) Review: Low-Frequency Collective Motion in Biomacromolecules and Its Biological Functions. Biophysical Chemistry, 30, 3-48.

https://doi.org/10.1016/0301-4622(88)85002-6

[17] Chou, K.C. and Forsen, S. (1980) Diffusion-Controlled Effects in Reversible Enzymatic Fast Reaction System: Critical Spherical Shell and Proximity Rate Constants. Biophysical Chemistry, 12, 255-263. https://doi.org/10.1016/0301-4622(80)80002-0

[18] Chou, K.C. and Forsen, S. (1980) Graphical Rules for Enzyme-Catalyzed Rate Laws. Biochemical Journal, 187, 829-835. https://doi.org/10.1042/bj1870829

[19] Chou, K.C., Forsen, S. and Zhou, G.Q. (1980) Three Schematic Rules for Deriving Apparent Rate Constants. Chemica Scripta, 16, 109-113.

[20] Chou, K.C., Li, T.T. and Forsen, S. (1980) The Critical Spherical Shell in Enzymatic Fast Reaction Systems. Biophysical Chemistry, 12, 265-269. 
https://doi.org/10.1016/0301-4622(80)80003-2

[21] Li, T.T., Chou, K.C. and Forsen, S. (1980) The Flow of Substrate Molecules in Fast Enzyme-Catalyzed Reaction Systems. Chemica Scripta, 16, 192-196.

[22] Chou, K.C., Carter, R.E. and Forsen, S. (1981) A New Graphical Method for Deriving Rate Equations for Complicated Mechanisms. Chemica Scripta, 18, 82-86.

[23] Chou, K.C. and Forsen, S. (1981) Graphical Rules of Steady-State Reaction Systems. Canadian Journal of Chemistry, 59, 737-755. https://doi.org/10.1139/v81-107 